\title{
Structural change, marginal land and economic development in Latin America and the Caribbean
}

\author{
Edward B. Barbier · John S. Bugas
}

Received: 14 August 2013/ Accepted: 31 August 2013/Published online: 15 February 2014

(C) The Author(s) 2014. This article is published with open access at Springerlink.com

\begin{abstract}
Empirical evidence indicates that in Latin America and the Caribbean, households on less favored, or marginal, agricultural land form a "residual" pool of rural labor. Although the modern sector may be the source of dynamic growth through learning-by-doing and knowledge spillovers, patterns of labor, land and other natural resources use in the rural economy matter in the overall dynamics of structural change. The concentration of rural populations on marginal land is essentially a barometer of economy-wide development. As long as there is abundant marginal land for cultivation, they serve to absorb rural migrants, increased population, and displaced unskilled labor from elsewhere in the economy. Moreover, the economy is vulnerable to the "Dutch disease" effects of a booming primary products sector. As a consequence, productivity increases and expansion in the commercial primary production sector will cause manufacturing employment and output to contract, until complete specialization occurs. Avoiding such an outcome and combating the inherent dualism of the economy require both targeted polices for the modern sector and traditional agriculture on marginal land.
\end{abstract}

Keywords Latin America $\cdot$ Structural change $\cdot$ Rural poverty $\cdot$ Less favored land · Dualism · Primary products

JEL Classification $\mathrm{O} 13 \cdot \mathrm{O} 44 \cdot \mathrm{Q} 15$

\section{Introduction}

The purpose of the following paper is to show that structural transformation in Latin American and Caribbean (LAC) economies depends crucially on the pattern of

E. B. Barbier $(\bowtie)$ J. S. Bugas

Department of Economics and Finance, University of Wyoming, Laramie, WY 82071, USA

e-mail: ebarbier@uwyo.edu 
production, land expansion and resource use in the rural economy. That is, even if the modern sector is the source of dynamic growth through learning-by-doing and knowledge spillovers, how labor and land (including natural resources) are utilized in the rural economy matters to the overall dynamics of structural change. In particular, in Latin America and the Caribbean, the rural economy comprises two separate sectors that exhibit distinctly different patterns of labor, land and natural resource use. One sector consists of commercially oriented activities that convert and exploit available land and natural resources for a variety of traded primary product outputs. The other sector contains smallholders employing traditional methods to cultivate less favorable agricultural land.

As a consequence, the rural economy displays Ricardian land surplus conditions, as first identified by Hansen (1979). ${ }^{1}$ Because there is an unlimited supply of marginal land with negligible productivity, smallholders practicing traditional agriculture earn no rents. Real wages are invariant to rural employment and determined by the average product of labor. The result is that the more productive and dynamic modern sector competes with the commercial primary production sector for available labor, with marginal land absorbing the residual.

Essentially, the concentration of rural populations on less favored, or marginal, agricultural land is the barometer of economy-wide development. As long as there is abundant marginal land for cultivation, it absorbs rural migrants, population increases and displaced unskilled labor from elsewhere in the economy. Moreover, the economy is vulnerable to the type of "Dutch disease" effects of a booming primary products sector first analyzed by Matsuyama (1992), and also observed for LAC economies (Astorga 2010; Barbier 2004; López 2003; Maloney 2002). Rising commodity prices will cause manufacturing employment and output to contract while the primary sector expands, until complete specialization occurs. Avoiding such an outcome and combating the inherent dualism of the economy require both targeted polices for the modern sector and traditional agriculture on marginal land.

The paper is organized as follows. The next section provides evidence on the two key stylized facts of land use and rural poverty in LAC countries. The subsequent section develops a dual economy model, with the rural sector displaying Ricardian "land surplus" conditions. The influence of primary product price booms and the implementation of targeted policies for the modern sector and traditional agriculture on marginal land are then analyzed. Finally, the paper includes an empirical analysis of long-run growth over 1990-2011 for 35 LAC economies to test some of the predictions of the dual economy model.

\section{Land use and rural poverty in Latin America}

Land use change is critically bound with the pattern of economic development in Latin America and the Caribbean. There are two aspects to this pattern. First, the economies of the region are still largely dependent on primary products for their export earnings. For LAC countries, $55.3 \%$ of merchandise exports consist of

\footnotetext{
${ }^{1}$ For an updated treatment of these conditions, see Barbier (in press).
} 


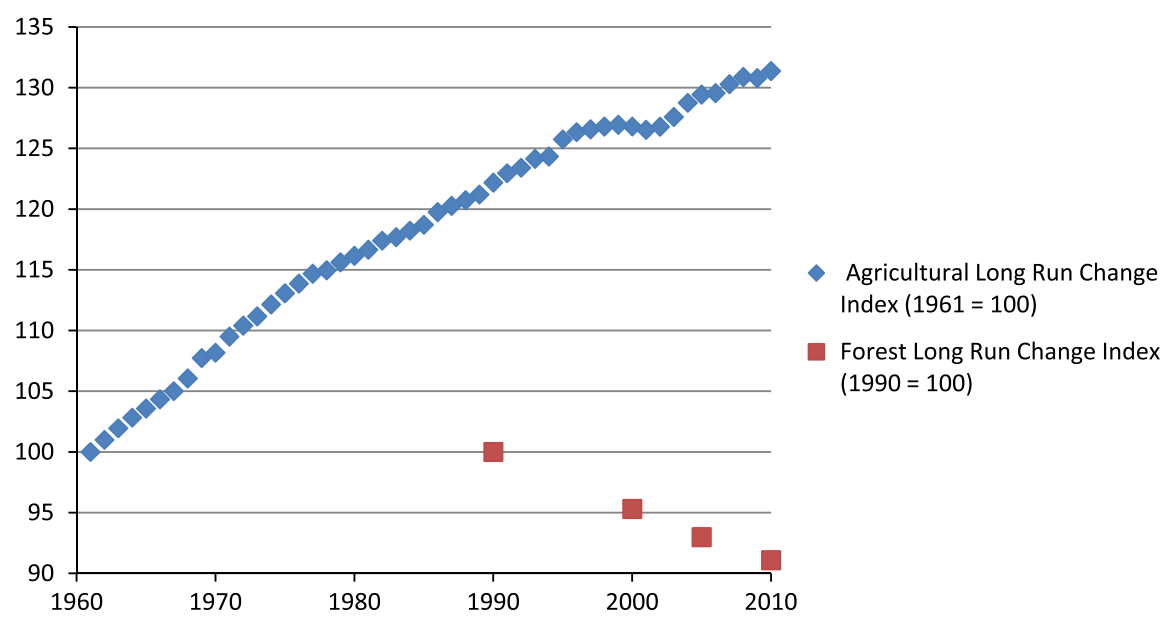

Fig. 1 Long-run land use change in Latin American and Caribbean, 1961-2011. Source World Bank (2013)

primary products, which comprise agricultural raw materials (1.7\%), food (17.9\%), fuel (23.1\%), and ores and metals (12.6 \%) (World Bank 2013). Despite the region's efforts to diversify exports, for many LAC economies one or two major primary products still accounts for a significant share of total exports (Jiménez and Tromben 2006). Second, over the past 50 years, and especially in LAC developing economies, cropland area has continued to expand (see Fig. 1). In the region, tropical forests were the primary sources of new agricultural land in the 1980s and 1990s (Gibbs et al. 2010). That trend appears to have continued since 1990 (Fig. 1). Despite some reforestation in the region, net forest loss over 2001-2010 amounted to over $179,000 \mathrm{~km}^{2}$ (Aide et al. 2013). Extensive conversion of forests, wetlands and other non-cultivated land is expected to continue through 2030, as new land is required for agricultural and biofuel crops, grazing pasture, industrial forestry, and to replace land lost to degradation (Lambin and Meyfroidt 2011).

For Latin America and the Caribbean, the current pattern of resource and land use also has two important implications for the structure of the rural sector.

First, expansion of less favored, or "marginal", agricultural land is occurring primarily to meet the subsistence and near-subsistence needs of rural households. That is, many of the region's rural poor continue to be concentrated in less ecologically favored and remote areas, such as converted forest frontier areas, poor quality uplands, converted wetlands, and similar land with limited agricultural potential (Barbier 2010, 2012; Comprehensive Assessment of Water Management in Agriculture 2007; CPRC 2004; IFAD 2010; World Bank 2003, 2008). This is not a new phenomenon; as noted by Coxhead et al. (2002, p. 345), "the land frontier has long served as the employer of last resort for underemployed, unskilled labor". For many LAC countries, this process has long been a major structural feature (Aldrich et al. 2006; Barbier 2011; Borras et al. 2012; Browder et al. 2008; Carr 2009a, b; Caviglia-Harris et al. 2013; Mueller 1997; Pacheco et al. 2011; Pichón 1997; Solís 
et al. 2009). Population increases, rural migration and other economic pressures mean that marginal land expansion will continue to absorb the growing number of rural households in the region. The result is that the rural poor located on marginal and low productivity agricultural land typically employ traditional farming methods, earn negligible land rents or profits, and have inadequate access to transport, infrastructure and markets (Aldrich et al. 2006; Barbier 2010, 2012; Banerjee and Duflo 2007; Browder et al. 2008; Caviglia-Harris and Harris 2008; Caviglia-Harris et al. 2013; IFAD 2010; Jalan and Ravallion 1997; Solís et al. 2009).

Second, less favorable agricultural land may be an important outlet for the rural poor, but increasingly commercially oriented economic activities are responsible for much of the resource exploitation and expansion of the agricultural land base that is occurring in LAC economies (Aide et al. 2013; Borras et al. 2012; Boucher et al. 2011; Chomitz et al. 2007; DeFries et al. 2010; FAO 2006; Pacheco et al. 2011; Rudel 2007). The primary product activities responsible for extensive land conversion include plantation agriculture, ranching, forestry and mining activities, and often result in export-oriented extractive enclaves with little or no forward and backward linkages to the rest of the economy (Barbier 2011; Borras et al. 2012; Bridge 2008; Jiménez and Tromben 2006; Pacheco et al. 2011; van der Ploeg 2011). In addition, developing countries have been actively promoting these commercial activities as a means to expand the primary products sector, especially in the land and resource abundant regions of Latin America (Borras et al. 2012; Deininger and Byerlee 2012; Pacheco et al. 2011; Rudel 2007). The result is that many LAC economies still depend on the exploitation of natural resources and are unable to diversify from primary production as the dominant economic sector (Astorga 2010; Jiménez and Tromben 2006).

Table 1 indicates the link between low levels of GDP per capita, poverty, the concentration of rural populations on less favored agricultural land and resource dependency for LAC economies. All data in the table are for 2011, or the latest year, with the exception for less favored agricultural land, which is a 2010 estimate. On average across 35 LAC countries, real GDP per capita is $\$ 6,007,25.3 \%$ of the rural population is located on less favored agricultural land, the poverty rate is $41.2 \%$, the share of primary products in total exports is 63.5 , and $20.8 \%$ of the workforce is in industry. However, the table also confirms that the lower income economies, with real GDP per capita below $\$ 6,000$, have more of their rural populations concentrated on less favored agricultural land, display higher poverty rates, and are more resource dependent, in terms of a higher share of primary product exports but a lower share of industry employment. The lowest income countries, with less than $\$ 3,000$ real GDP per capita, have the highest concentration of rural populations on less favored agricultural land and the greatest poverty rates.

Figure 2 confirms the negative correlation between levels of GDP per capita (in 2011 or latest year) and the share of rural populations on less favored agricultural land across Latin America and the Caribbean (in 2010). Those LAC economies that are relatively poorer tend to have more of the rural population concentrated on marginal agricultural land, whereas the rich LAC countries tend to have lower concentrations of their rural population on less favored agricultural land. 
Table 1 Population on marginal land, GDP per capita, poverty and resource dependency

\begin{tabular}{|c|c|c|c|c|c|}
\hline Income group & $\begin{array}{l}\text { GDP per } \\
\text { capita }(2000 \\
\text { US\$) }\end{array}$ & $\begin{array}{l}\text { Rural population } \\
(\%) \text { on less } \\
\text { favored agricultural } \\
\text { land }\end{array}$ & $\begin{array}{l}\text { Poverty } \\
\text { headcount } \\
\text { ratio }(\%)\end{array}$ & $\begin{array}{l}\text { Primary } \\
\text { product } \\
\text { export } \\
\text { share }(\%)\end{array}$ & $\begin{array}{l}\text { Industry } \\
\text { employment } \\
\text { share }(\%)\end{array}$ \\
\hline Less than $\$ 3,000$ & $\$ 1,631$ & 31.7 & 58.9 & 64.3 & 19.2 \\
\hline Haiti & $\$ 386$ & 59.9 & 88.0 & 15.8 & 10.8 \\
\hline Guyana & $\$ 1,211$ & 7.8 & & 92.6 & 22.8 \\
\hline Nicaragua & $\$ 1,221$ & 35.2 & 63.3 & 94.0 & 16.5 \\
\hline Bolivia & $\$ 1,276$ & 23.6 & 66.4 & 96.0 & 20.0 \\
\hline Honduras & $\$ 1,414$ & 25.7 & 71.6 & 63.5 & 18.5 \\
\hline Paraguay & $\$ 1,658$ & 47.2 & 44.8 & 89.3 & 17.1 \\
\hline Ecuador & $\$ 1,837$ & 17.5 & 50.9 & 92.1 & 18.6 \\
\hline Guatemala & $\$ 1,886$ & 35.7 & 71.4 & 60.6 & 22.8 \\
\hline El Salvador & $\$ 2,579$ & 64.4 & 46.5 & 27.5 & 21.4 \\
\hline Surname & $\$ 2,840$ & 0.4 & 27.2 & 11.8 & 23.0 \\
\hline$\$ 3,000-\$ 6,000$ & $\$ 4,413$ & 25.8 & 36.9 & 71.2 & 19.6 \\
\hline Peru & $\$ 3,360$ & 15.8 & 56.5 & 86.2 & 23.7 \\
\hline Colombia & $\$ 3,362$ & 32.8 & 46.1 & 82.6 & 20.0 \\
\hline Belize & $\$ 3,490$ & 6.2 & 44.2 & 98.3 & 17.9 \\
\hline Jamaica & $\$ 3,505$ & 40.3 & 17.6 & 59.6 & 16.1 \\
\hline Dominican Republic & $\$ 4,176$ & 34.1 & 48.4 & 33.1 & 21.9 \\
\hline Cuba & $\$ 4,495$ & 34.7 & & 73.1 & 17.0 \\
\hline Brazil & $\$ 4,803$ & 26.2 & 21.4 & 63.9 & 22.1 \\
\hline St. Vincent and Gren. & $\$ 4,845$ & 25.1 & & 83.8 & 19.6 \\
\hline Costa Rica & $\$ 5,368$ & 31.7 & 29.3 & 39.6 & 19.8 \\
\hline St. Lucia & $\$ 5,470$ & 17.6 & & 65.4 & 16.1 \\
\hline Venezuela & $\$ 5,672$ & 19.3 & 32.0 & 98.0 & 21.8 \\
\hline Over $\$ 6,000$ & $\$ 10,384$ & 20.2 & 23.5 & 56.3 & 22.8 \\
\hline Grenada & $\$ 6,047$ & 32.1 & & 58.9 & 23.9 \\
\hline Mexico & $\$ 6,288$ & 45.5 & 60.8 & 27.0 & 25.5 \\
\hline Dominica & $\$ 6,519$ & 8.0 & & 33.9 & 19.8 \\
\hline Panama & $\$ 6,654$ & 24.4 & 59.8 & 86.8 & 18.6 \\
\hline Chile & $\$ 7,123$ & 17.5 & 12.9 & 86.2 & 23.0 \\
\hline Argentina & $\$ 8,717$ & 28.1 & 1.9 & 65.4 & 23.8 \\
\hline Barbados & $\$ 9,244$ & 32.0 & & 40.2 & 20.3 \\
\hline Uruguay & $\$ 9,581$ & 50.5 & 6.0 & 74.5 & 21.1 \\
\hline St. Kitts and Nevis & $\$ 9,944$ & 0.8 & & 11.9 & 48.9 \\
\hline Antigua and Barbuda & $\$ 9,978$ & 7.4 & & 63.1 & 15.6 \\
\hline Trinidad and Tobago & $\$ 10,048$ & 9.1 & 13.5 & 69.0 & 32.2 \\
\hline
\end{tabular}


Table 1 continued

\begin{tabular}{|c|c|c|c|c|c|}
\hline Income group & $\begin{array}{l}\text { GDP per } \\
\text { capita }(2000 \\
\text { US\$) }\end{array}$ & $\begin{array}{l}\text { Rural population } \\
(\%) \text { on less } \\
\text { favored agricultural } \\
\text { land }\end{array}$ & $\begin{array}{l}\text { Poverty } \\
\text { headcount } \\
\text { ratio }(\%)\end{array}$ & $\begin{array}{l}\text { Primary } \\
\text { product } \\
\text { export } \\
\text { share }(\%)\end{array}$ & $\begin{array}{l}\text { Industry } \\
\text { employment } \\
\text { share }(\%)\end{array}$ \\
\hline Puerto Rico & $\$ 16,910$ & 15.3 & & & 13.6 \\
\hline 'Aruba & $\$ 18,853$ & 11.1 & & 81.3 & 20.3 \\
\hline Bahamas & $\$ 19,467$ & 0.8 & 9.3 & 33.4 & 12.9 \\
\hline All countries & $\$ 6,007$ & 25.3 & 41.2 & 63.5 & 20.8 \\
\hline
\end{tabular}

GDP per capita (\$2,000), 2011 or latest year, from World Bank (2013). Less favored agricultural land consists of irrigated land on terrain greater than $8 \%$ median slope; rainfed land with a length of growing period (LGP) of more than 120 days but either on terrain greater than $8 \%$ median slope or with poor soil quality; semi-arid land (land with LGP 60-119 days); and arid land (land with LGP <60-119 days). Estimates are for 2010 and based on GAEZ dataset. Poverty headcount rate at rural or national poverty line, 2011 or latest year, from World Bank (2013). Primary product export share is the percentage of agricultural raw material, food, fuel, ore and metal commodities to total merchandise exports, 2011 or latest year, from World Bank (2013). Industry employment share is the percentage of total employment in industry, 2011 or latest year, from World Bank (2013)

In sum, the pattern of land use and expansion prevalent throughout much of the LAC region is symptomatic of a dualistic rural economy. That is, the rural economy of many LAC countries contains both a traditional sector that converts and exploits available land to produce a non-traded agricultural output, and a fully developed, commercially oriented sector that converts and exploits available land and natural resources for a variety of traded outputs. The latter includes plantation agriculture, ranching, forestry and mining activities. In addition, the traditional agricultural sector is dominated by farm holdings that occupy marginal or ecologically fragile land with poor land quality and productivity potential. Although these two types of economic activities differ significantly and may also be geographically separated, they are linked by labor use, as the rural populations on marginal land form a large pool of surplus unskilled labor that can be employed in commercial primary production activities. This linkage is important not only to the dynamics of land expansion and use within economies but also to the overall structure of economic development (Barbier 2013).

\section{A model of a land surplus rural economy}

Following the above discussion of land use change in Latin America and the Caribbean, it is assumed that the rural economy displays land surplus characteristics. In addition, it comprises two separate sectors that exhibit distinctly different patterns of labor, land and natural resource use. One sector consists of commercially oriented activities that convert and exploit available land and natural resources for a variety of traded primary product outputs. Land and other natural resources are sufficiently abundant for use in primary production, but can only be appropriated through employing an increasing amount of labor for this purpose. The other rural 


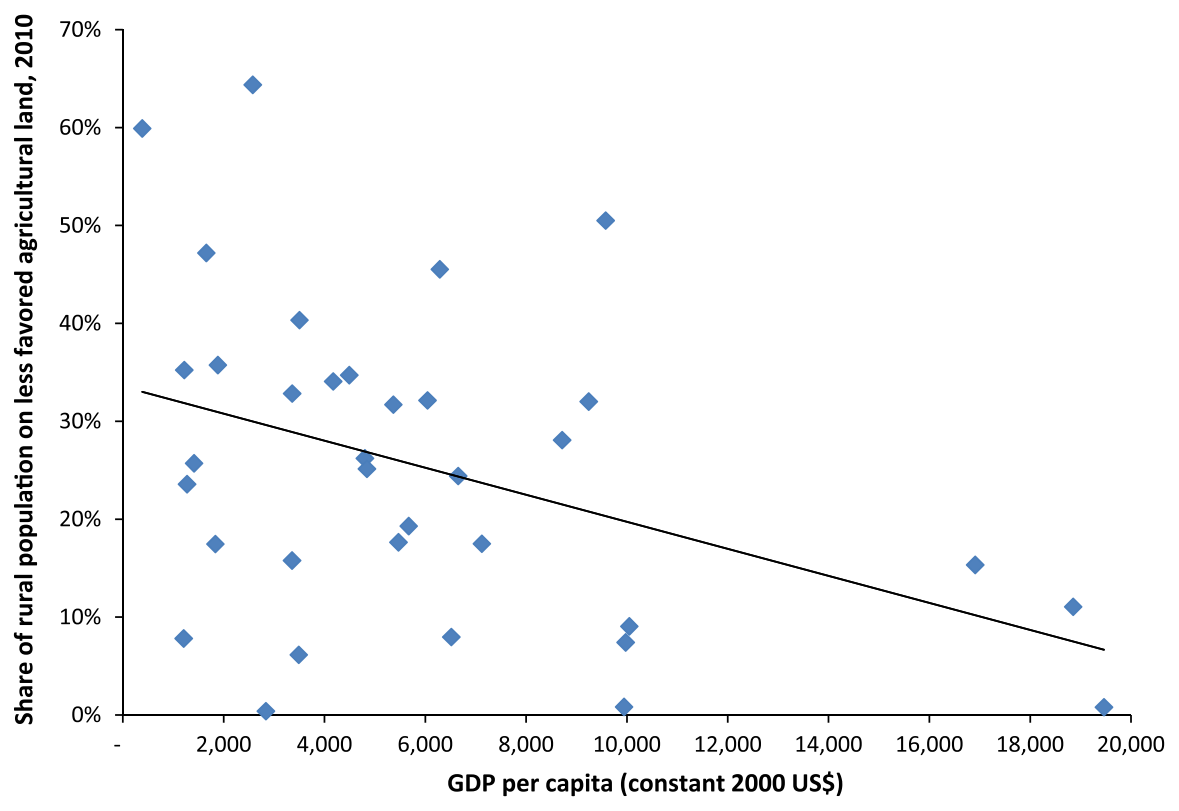

Fig. 2 GDP per capita and population on marginal land, LAC economies. Notes GDP per capita $(\$ 2,000), 2011$ or latest year, is from World Bank (2013). Less favored agricultural land consists of irrigated land on terrain greater than $8 \%$ median slope; rainfed land with a length of growing period (LGP) of more than 120 days but either on terrain greater than $8 \%$ median slope or with poor soil quality; semi-arid land (land with LGP 60-119 days); and arid land (land with LGP <60-119 days). Estimates are for 2010 and based on GAEZ dataset. Number of observations $=35$ countries. Average (median) real GDP per capita id \$6,007 $(\$ 4,845)$. Average (median) share of rural population on less favored agricultural land is $25.3 \%(25.1 \%)$. Pairwise correlation coefficient $r=-0.41$

sector contains smallholders employing traditional methods to cultivate less favorable agricultural land. For these smallholders, land is also abundant but of extremely poor quality for agricultural production. There is perfect labor mobility throughout the dualistic rural economy.

In addition to the rural economy, there is a modern or leading sector. Following models of structural transformation in developing countries, "the modern sector basically comprises industry along with parts of agriculture and services" (Ocampo et al. 2009, p. 122). Firms in this sector employ capital and labor, innovate through learning-by-doing technological change and generate knowledge spillovers. There is perfect labor mobility between the rural economy and the modern sector.

\subsection{Commercial primary production}

In this rural sector, production of the primary product (plantation crops, timber, beef, mineral, etc.) depends directly on inputs of land and/or natural resources $N_{1}$ and labor $L_{1}$; any capital input is fixed and fully funded out of normal profits. Primary production $Q_{1}$ is determined by a function with the normal concave properties and is homogeneous of degree one 


$$
Q_{1}=F\left(N_{1}, L_{1}\right), F_{i}>0, F_{i i}<0, \quad i=N, L .
$$

The commercial activity can obtain more land or natural resources (hereafter referred to as "resource") for primary production, but only by employing and allocating more labor for this purpose. It is assumed that increasing $N_{1}$ incurs a rising input of $L_{1}$

$$
L_{1}=z\left(N_{1}\right), z^{\prime}>0, z^{\prime \prime} \geq 0,
$$

where $z^{\prime}\left(N_{1}\right)$ is the marginal labor requirement of obtaining and transforming a unit of the resource input, which is a convex function of the amount of $N_{1}$ appropriated.

Letting $p_{1}$ be the world price of traded primary products and $w$ the wage rate, it follows that total profits are $\pi=L_{1}\left[p_{1} f\left(n_{1}\right)-w\right]=L_{1}\left[p_{1} f\left(z^{-1}\left(L_{1}\right) / L_{1}\right)-w\right]$, $n_{1}=N_{1} / L_{1}, f\left(n_{1}\right)=F\left(N_{1} / L_{1}, 1\right)$. Profit-maximizing, therefore, leads to

$$
f\left(n_{1}\right)+f_{N}\left(n_{1}\right)\left[\frac{1}{z^{\prime}\left(N_{1}\right)}-n_{1}\right]=f\left(n_{1}\right)-f_{N}\left(n_{1}\right) n_{1}\left[1-\varepsilon\left(N_{1}\right)\right]=\frac{w}{p_{1}}, \quad 0<\varepsilon\left(N_{1}\right)<1,
$$

where $\varepsilon\left(N_{1}\right) \equiv \frac{\partial N_{1}}{\partial L_{1}} \frac{L_{1}}{N_{1}}=\frac{1}{z^{\prime} n_{1}}$ is the elasticity of resource conversion, i.e., the percentage increase in resources appropriated for primary production in response to proportionately more labor devoted to this purpose. It is assumed that the normal case is $0<\varepsilon\left(N_{1}\right)<1$. $^{2}$ Condition (3) indicates that labor will be used in commercial primary production activities until its value marginal productivity equals the wage rate. As labor is used for both appropriating resources and production, the wage rate will be higher if resources are fixed in supply and thus labor was used only for production $\left(\varepsilon\left(N_{1}\right)=0\right)$. Because in (3) the value marginal productivity of labor declines with respect to $L_{1}$, the wage rate is a decreasing function of labor employed in the primary product sector.

\subsection{Traditional agriculture on marginal land}

Production of non-traded agricultural output on less favored, or marginal, land also involves two inputs, land $\left(N^{m}\right)$ and labor $\left(L^{m}\right)$; any capital input is fixed and fully funded out of normal profits. Both land and labor are required for traditional agricultural production, $Q^{m}$, which is determined by the following linearly homogeneous function

$$
Q^{m}=G\left(N^{m}, L^{m}\right), G_{i} \geq 0, G_{i i}<0, \quad i=N, L
$$

Note that the marginal productivity of land is not necessarily positive, which is the case for all less favored agricultural land. This Ricardian surplus land condition follows from the assumption that poor quality marginal land is unproductive in cultivation (Hansen 1979). That is, for traditional agriculture on less favored land

\footnotetext{
2 The case $\varepsilon\left(N_{1}\right)=1$ implies $\partial L_{1} / \partial N_{1}=L_{1} / N_{1}=z$, which is a violation of the convex properties of (2). It also corresponds to the case first suggested by Domar (1970), where natural resources and land are so abundant that they essentially comprise a limitless "frontier" that they can be appropriated proportionately with increases in labor. In contrast, if $\varepsilon\left(N_{1}\right)=0$, then resources are no longer abundantly available but fixed in supply.
} 
$G_{N}=0$, and because (3) does not apply to marginal land conversion, equilibrium is determined by

$$
g_{N}\left(n^{m}\right)=0, \quad q^{m}=g\left(n^{m}\right)=\frac{w}{p^{m}}, \quad n^{m}=\frac{N^{m}}{L^{m}}, \quad q^{m}=\frac{Q^{m}}{L^{m}}=G\left(N^{m} / L^{m}, 1\right) .
$$

The result is that there are no diminishing returns to labor in the use of less favored land for agricultural production. Real wages are invariant to rural employment and determined by the average product of labor. Moreover, the condition of zero marginal productivity fixes the land-labor ratio on less favored agricultural land, which can be designated as $n^{m}$. Given the average product of labor relationship in (5), the fixed land-labor ratio will determine the nominal wage rate $w$ for the predetermined output price $p^{m}$. Thus, the best that rural households on less favored agricultural land can do is either to sell their labor to each other and obtain an equilibrium real wage $w / p^{m}$, or alternatively, farm their own plots of land and earn the same real wage. Since there is little advantage in selling their labor, households will tend to use their labor to farm their own land. Hence, under this marginal land condition, small family farms consuming their own production will predominate. Unless the population increases, no more land will be brought into production and there will be surplus of unfarmed less favored land.

\subsection{Modern sector}

The modern sector, which includes industry but also technically advanced agriculture and services, has labor-augmenting technology that benefits from learning-by-doing and knowledge spillovers. Production in the sector depends on both unskilled labor and capital, which could also comprise human capital (skills). For the representative firm, an increase in the firm's capital stock leads to a parallel increase in its stock of knowledge. Each firm's knowledge is a public good, however, that any other firm can access at zero cost.

For the representative $i$ th firm, output $Q_{2 i}$ is produced by hiring capital $K_{2 i}$ and labor $L_{2 i}$, and $A_{2 i}$ is the amount of labor-augmenting technology available to the firm. But, with the presence of learning-by-doing and knowledge spillovers $A_{2 i}=$ $K_{2}=\sum_{i} K_{2 i}$ and the representative firm's production function is

$$
Q_{2 i}=H\left(K_{2 i}, A_{2 i} L_{2 i}\right)=H\left(K_{2 i}, K_{2} L_{2 i}\right), H_{j}>0, H_{j j}<0, \quad j=K, L .
$$

Production of the firm displays diminishing returns to its own stock of capital $K_{2 i}$, provided that $K_{2}$ and $L_{2 i}$ are constant. However, if each producer in the sector expands its own capital, then $K_{2}$ will rise and produce a spillover benefit that increases the productivity of all firms, which is the increasing returns effect. Each firm's production is nonetheless homogeneous of degree one with respect to its own capital $K_{2 i}$ and labor $L_{2 i}$, and if $K_{2 i}$ and $K_{2}$ expand together by the same amount while $L_{2 i}$ is fixed, production also displays constant returns to scale.

For each firm, the total capital stock $K_{2}$ of the modern sector is exogenously determined. In addition, assume that the output of each firm is a homogenous 
product with a given price $p_{2}$. If all firms make the same choices so that $k_{2 i}=k_{2}$ and $K_{2}=k_{2} L_{2}$, then profit-maximizing by each firm yields

$$
\begin{gathered}
p_{2} h_{K}\left(k_{2}, K_{2}\right)=p_{2}\left[\tilde{h}\left(L_{2}\right)-L_{2} \tilde{h}^{\prime}\left(L_{2}\right)\right]=r, \quad q_{2}=\frac{Q_{2}}{L_{2}}=h\left(k_{2}, K_{2}\right) \\
h\left(k_{2}, K_{2}\right)-k_{2} h_{K}\left(k_{2}, K_{2}\right)=K_{2} \tilde{h}^{\prime}\left(L_{2}\right)=\frac{w}{p_{2}}
\end{gathered}
$$

where use is made of the following expressions for the average product of capital $\tilde{h}\left(L_{2}\right)$ and private marginal product of capital $h_{K}\left(k_{2}, K_{2}\right)$, respectively.

$$
\begin{aligned}
\frac{h\left(k_{2}, K_{2}\right)}{k_{2}} & =\tilde{h}\left(\frac{K_{2}}{k_{2}}\right)=\tilde{h}\left(L_{2}\right), h_{K}\left(k_{2}, K_{2}\right) \\
& =\tilde{h}\left(L_{2}\right)-L_{2} \tilde{h}^{\prime}\left(L_{2}\right), \tilde{h}^{\prime}\left(L_{2}\right)>0, \tilde{h}^{\prime \prime}\left(L_{2}\right)<0 .
\end{aligned}
$$

Condition (7) indicates that the value marginal productivity of capital for a modern sector firm equals the interest rate, $r$. Condition (8) indicates that the value marginal productivity of labor employed by a modern sector firm equals the real wage rate.

Both the private marginal product of capital and average product of capital are invariant with respect to the capital-labor ratio because learning-by-doing and spillovers eliminate diminishing returns to capital. As (9) indicates, the private marginal product of capital is less than the average marginal product of capital. The private marginal product of capital is increasing in $L_{2}$, given $\tilde{h}^{\prime \prime}\left(L_{2}\right)<0$. These results (7)-(9) for production and input use involving learning-by-doing and knowledge spillovers are standard for these types of relationships (Barro and Sala-IMartin 2004).

\subsection{Primary production trade, growth dynamics and labor market equilibrium}

Because condition (5) indicates that the fixed land-labor ratio on less favored land $n^{m}$ determines the nominal wage rate $w$, the rural economy is recursive with respect to resource use, labor and output in the primary production sector. If the elasticity of resource conversion $\varepsilon\left(N_{1}\right)$ is constant, $p_{1}$ given and $w$ known, then (3) yields the resource-land ratio $n_{1}$ for primary production. With $n_{1}$ determined, the relationship $\varepsilon=1 / z^{\prime} n_{1}$ can be solved for resource conversion and use $N_{1}$. Employment $L_{1}$, and from (1), primary production $Q_{1}$ can then be found.

Primary products are exported, and $p_{1}$ is the given world price for these commodities. These products are exchanged for imports $M$, which are substitutes for consumption of domestic output from the modern sector. The balance of trade is

$$
p Q_{1}=M, \quad p=\frac{p_{1}}{p_{2}}
$$

where $p$ is the terms of trade, expressed in terms of modern sector commodities as the numeraire. Note that, because $p$ is given and $Q_{1}$ known, imports to the small economy are recursively determined. 
If there is no population growth, the representative household seeks to maximize its discounted flow of welfare over time as given by $U=\int_{0}^{\infty}\left[\frac{\left(c^{1-\theta}+m^{1-\theta}\right)-1}{1-\theta}\right] e^{-\rho t} \mathrm{~d} t$ subject to the budget constraint $\dot{a}=r a+w-c$, where $m$ is per capita imports, $a$ is the household's assets per person, $r$ is the interest rate, $w$ the wage rate, $\rho$ is the rate of time preference, and $\theta$ is the intertemporal elasticity of substitution.

However, as imports are determined by the primary products balance of trade condition (6), the household is free to choose only its per capita consumption. As shown in the "Appendix", the growth dynamics of the modern sector and thus the economy are governed by

$$
\begin{gathered}
\dot{k}_{2}=p_{2} \tilde{h}\left(L_{2}\right) k_{2}-c, \quad k_{2}(0)=k_{20} \\
c(t)=\varphi k_{2}(t), \quad \varphi=p_{2} \tilde{h}\left(L_{2}\right)-\gamma \\
\frac{\dot{q}_{2}}{q_{2}}=\frac{\dot{k}_{2}}{k_{2}}=\frac{\dot{c}}{c}=\gamma, \quad \gamma=\frac{1}{\theta}\left(p_{2}\left[\tilde{h}\left(L_{2}\right)-L_{2} \tilde{h}^{\prime}\left(L_{2}\right)\right]-\rho\right)
\end{gathered}
$$

Equation (11) is the usual condition for capital accumulation in an economy. If output per capita, valued at the price $p_{2}$, exceeds consumption, and will increase capital per person. Condition (12) indicates that per capita consumption is proportional to capital per person. Consequently, as (13) depicts, capital and output per worker in the modern sector grow at the same (constant) rate as consumption per capita. The per capita growth rate, $\gamma$, is determined by the total number of workers employed in the sector, $L_{2}$. An expansion (contraction) in the aggregate modern sector labor force, $L_{2}$, therefore, increases (decreases) per capita growth in this sector.

With the nominal wage determined by the fixed land-labor ratio on less favored agricultural land, the value marginal productivity condition (8) for the modern sector must equal $w$. However, suppose that initially capital in the sector is some given level $K_{20}$. Equilibrium employment must, therefore, be the unique solution to $\tilde{h}^{\prime}\left(L_{2}\right)=w / p_{2} K_{20}$. It is possible that this level of employment is large enough so that growth of the modern sector is positive, i.e., $\gamma>0$. But this requires a relatively large initial stock of aggregate capital for the modern sector, as the equilibrium employment condition implies that more $L_{2}$ requires a higher $K_{20}$. For most LAC economies, the initial stock of aggregate capital in the modern sector is likely to be relatively small rather than large. Thus, it follows that employment $L_{2}$ will also be small, and if this is the case, it is more likely that (13) will yield $\gamma \leq 0$. If it turns out that $\gamma<0$, then the capital-labor ratio and aggregate capital will decline, employment will fall and the modern sector will contract.

It is also possible that the modern sector neither contracts nor declines. For example, with $w$ predetermined and for a given $K_{20}$, the equilibrium $L_{2}$ that satisfies (8) is just sufficient to ensure $\gamma=0$ in (13). This outcome ensures constant employment and aggregate capital in the modern sector, and thus an equilibrium output level $Q_{2}$. Such a steady-state result is depicted in Fig. 3.

The total labor force in the developing economy is $L=L_{1}+L_{2}+L^{m}$. With employment in primary production and the modern sector known, the residual labor 


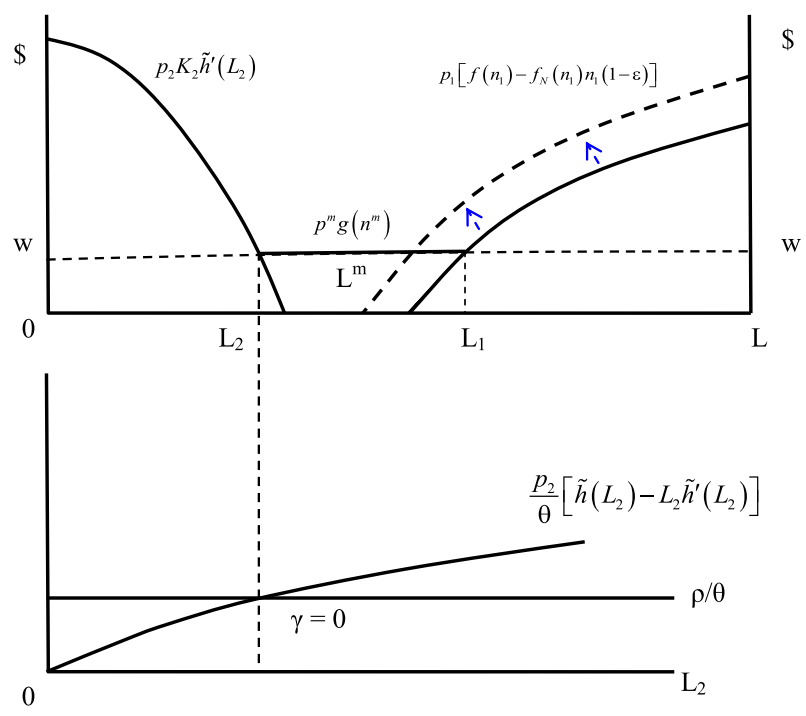

Fig. 3 Labor market equilibrium and growth in the land surplus economy

on marginal land $L^{m}$ can be found. As $n^{m}$ is already known, the total marginal land used in traditional agriculture $N^{m}$ is determined. Thus, the full labor market equilibrium corresponds to

$$
p_{1}\left[f\left(n_{1}\right)-f_{N}\left(n_{1}\right) n_{1}(1-\varepsilon)\right]=p_{2} K_{2} \tilde{h}^{\prime}\left(L_{2}\right)=p^{m} g\left(n^{m}\right)=w .
$$

As described previously, the average productivity of labor on marginal land determines the equilibrium wage rate in the economy, and employment in both the primary production and modern sectors equates their respective marginal productivities with $w$. In addition, the amount of labor employed in the modern sector $L_{2}$ must correspond to $\gamma=0$. The solid lines in Fig. 3 depict the labor market equilibrium for the economy and the corresponding zero growth rate for the modern sector.

The equilibrium outcome indicated in Fig. 3 is not very optimistic. Although some labor may be employed in the modern sector, a constant capital stock eliminates any productivity gains from spillover and learning-by-doing in the sector. As a consequence, the modern sector competes with the commercial primary production sector for available labor, with marginal land absorbing the residual. Without the dynamic productivity effects of positive growth, the modern sector does not generate a self-reinforcing labor absorption process that leads workers to shift from the rural economy to this sector. The economy remains fundamentally dualistic; commercial primary production and a static modern sector are the two principal sectors, with less favored agricultural land absorbing the remaining rural households. This latter process is a key structural feature of the land surplus rural economy. The concentration of the rural populations on marginal land is essentially a barometer of economy-wide development. As long as there is abundant less 
favored land for cultivation, it absorbs rural migrants, population increases and displaced unskilled labor from elsewhere in the economy.

On the other hand, the rural populations on less favored agricultural land can also be thought of as a large pool of unskilled surplus labor that, under the right conditions, could potentially be absorbed by the commercial primary production and modern sectors. These conditions are explored in turn.

\section{Primary product price boom}

Rising commodity prices frequently lead to expansion of the commercial primary product sector of developing countries (Barbier 2005, 2012; Deininger and Byerlee 2012; van der Ploeg 2011). In such instances, commodity price booms can provide some employment opportunities for low-skilled labor, and thus alleviate the pressure on marginal land less suitable for agriculture by smallholders. An example from Colombia illustrates that, if such employment opportunities are sufficiently large and sustained, they can actually reduce long-term less favored land expansion. In Colombia, since 1970 high-input, intensified, highly mechanized cropping on the most suitable land, as well as expansion in cattle grazing, has drawn labor from more traditional agriculture, so that areas of marginal land are slowly being abandoned and re-vegetating (Etter et al. 2008).

The labor, resource and less favored land impacts of a commodity price boom can be illustrated with the land surplus model. If $p_{1}$ rises, then real wages in the commercial primary products sector $w / p_{1}$ fall. The result is increased demand for labor $L_{1}$ in primary production. From (3), it follows that the resource-labor ratio for primary production $n_{1}$ must decline. However, from (2), attracting additional labor to the sector will lead in turn to more resource conversion. In order for $n_{1}$ to fall, the rise in $L_{1}$ must exceed the increase in $N_{1}$. With real wages unchanged in the modern sector, the increase in $L_{1}$ can come only from reducing labor on less favored land. The fall in $L^{m}$ must be accompanied by an equivalent decline in $N^{m}$ in order to keep the fixed land-labor ratio on marginal land. Thus, the increase in employment, resource use and output in the primary production sector in response to the rise in $p_{1}$ will reduce labor, cultivation and production on less favored land. In Fig. 3, this outcome is represented by the dotted lines that indicate the shifting out of the marginal productivity curve for labor use in primary production.

Of course, if the price of primary products falls, the opposite occurs. The commercial-oriented primary sector contracts, $L_{1}$ falls and the resulting surplus labor is absorbed on less favored land. The result of rise in $L^{m}$ is more land conversion until the land-labor ratio on marginal land returns to $n^{m}$. Once again, less favored land expansion serves as an outlet for residual rural labor, in this case the unemployed are displaced from commercial primary production as the result of a commodity price "bust". Such short-term boom and bust patterns of commercial primary products expansion occur frequently for many LA countries, including commodities such as cattle, cocoa, coffee, grains, oil palm, shrimp, sugar and other key primary products (Aldrich et al. 2006; Barbier 2011; Borras et al. 2012; Bridge 2008; Browder et al. 2008; Caviglia-Harris et al. 2013; DeFries et al. 2010; Mann 
et al. 2010; Pacheco et al. 2011; Rodrigues et al. 2009; Sills and Caviglia-Harris 2008).

However, even if the commodity price boom is sustained, it can have long-term consequences for the overall pattern of economic development. Suppose that commodity price rises continue to lower real wages in the primary product sector, so that the productivity curve in Fig. 3 shifts further to the left until all the surplus labor on less favored land $L^{m}$ is absorbed as $L_{1}$. Any further increases in the marginal productivity of labor in primary production will have an impact on the wage rate of the economy, as the labor market equilibrium is now

$$
p\left[f\left(\frac{N_{1}}{L-L_{2}}\right)-f_{N}\left(\frac{N_{1}}{L-L_{2}}\right) \frac{N_{1}}{L-L_{2}}[1-\varepsilon]\right]=K_{2} \tilde{h}^{\prime}\left(L_{2}\right)=w .
$$

Equilibrium condition (15) indicates that labor is allocated between primary production and manufacturing until its value marginal products in the two sectors are equalized. This equilibrium also determines the nominal wage.

As a consequence, as shown in Fig. 4, any further shifting out of the value marginal product curve for $L_{1}$ due to rising commodity prices will cause the nominal wage rate to rise. As $p_{2}$ in the modern sector remains unchanged, real wages will rise and the demand for $L_{2}$ declines. The unemployed labor will shift to the primary production sector instead. Although nominal wages have also risen for primary producers, the increase in $p_{1}$ must be sufficiently large to cause real wages in the sector to fall, in order for it to absorb the additional workers $L-L_{2}$. Similarly, resource conversion and use $N_{1}$ will increase for primary production, but less than the increase in $L_{1}$, so that the resource-labor ratio $n_{1}$ still declines.

However, the shift in labor from the modern sector to primary production will also lead to dynamic changes to the economy. As indicated by the dotted lines in Fig. 4, if workers leave the modern sector, then from (13), the fall in $L_{2}$ causes the per capita growth rate in the modern sector to become negative $\gamma<0$. Capital per person in the economy will now be falling, which implies a declining capital stock $K_{2}$. In this case, the marginal productivity of labor in manufactures will decline, causing more labor to shift to primary production. Growth will continue to fall, primary production expands and manufacturing disappears, until the economy becomes fully specialized in primary production. This outcome is similar to the Dutch disease "resource dependency" phenomenon first identified by Matsuyama (1992), and also observed for LAC economies at various times (Astorga 2010; Barbier 2004; López 2003; Maloney 2002). In a small open economy, productivity increases in a traded agricultural or primary producing sector will cause manufacturing employment and output to contract while the primary sector expands, until complete specialization occurs.

\section{Targeted policies for the modern sector}

The equilibrium outcome for the land surplus economy depicted in Fig. 3 indicates a static modern sector displaying zero per capita growth. Without the dynamic productivity effects of positive growth, the modern sector is unable to generate the 


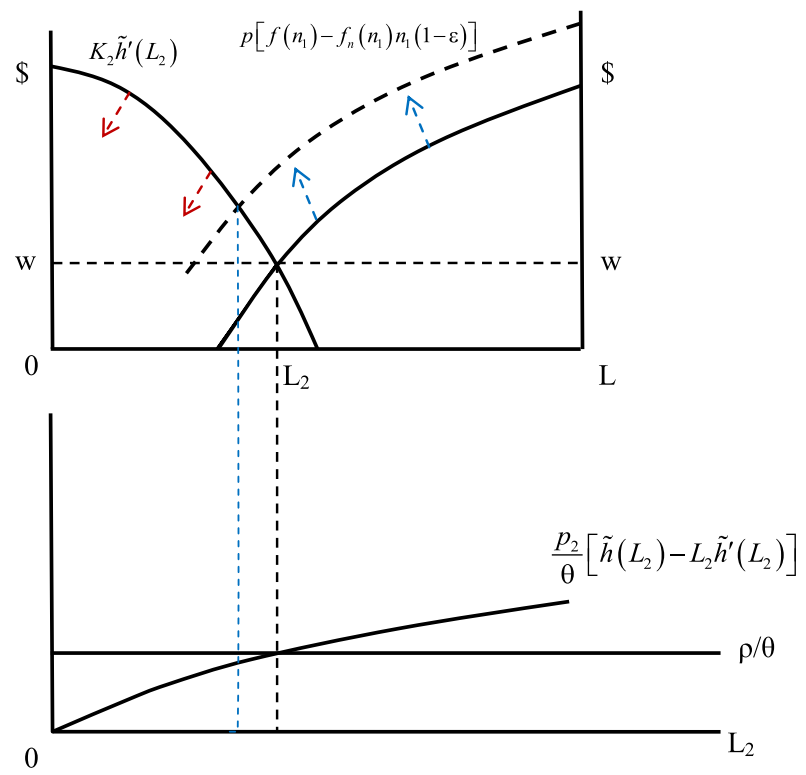

Fig. 4 Specialization in primary production

self-reinforcing labor absorption process that causes workers to shift from the rural economy to this sector, and the overall economy remains dualistic.

However, as indicated in the "Appendix", the growth outcome for the modern sector as represented by condition (13) is the result of the decentralized decisions made by competitive firms and households. Because individual producers in the modern sector do not internalize the learning-by-doing and spillover effects of capital accumulation, they base their decisions on the private marginal product of capital (see 7). In contrast, as shown in the "Appendix", the optimal growth for the modern sector should internalize learning-by-doing and knowledge spillovers across the sector. If so, then optimal modern sector growth is not determined by (13), but in accordance with the average product of capital, i.e.,

$$
\frac{\dot{q}_{2}}{q_{2}}=\frac{\dot{k}_{2}}{k_{2}}=\frac{\dot{c}}{c}=\gamma^{*}, \quad \gamma^{*}=\frac{1}{\theta}\left(p_{2} \tilde{h}\left(L_{2}^{*}\right)-\rho\right) .
$$

A comparison between (13) and (16) indicates that $\gamma^{*}>\gamma$. The optimal growth of the modern sector exceeds growth based solely on the decentralized decisions of consumers and firms.

As indicated in the "Appendix", a targeted policy intervention could ensure that the decentralized economy of the modern sector can still attain the higher socially optimal growth rate $\gamma^{*}$. Specifically, a lump sum tax on the wages of consumers could be used to subsidize purchases of capital goods, through mechanisms such as an investment tax credit, and thus effectively ensure that individual producers are making decisions based on the average product of capital. Such a targeted policy has the possibility of ensuring that the modern sector escapes the "zero growth" trap depicted in Fig. 3. 


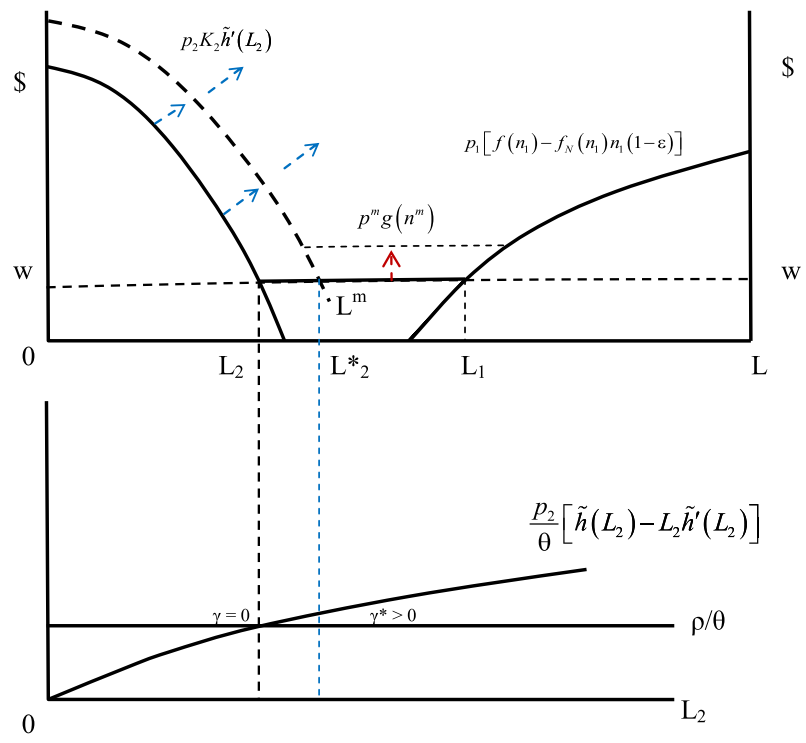

Fig. 5 Targeted policies in the modern sector

For example, if the growth rate $\gamma=0$ in Fig. 3 corresponds to the decentralized decision of producers based on the private marginal productivity of capital (7), then a subsidy for capital purchases will raise the growth rate to $\gamma^{*}>0$. However, as (16) indicates, this must correspond to a higher rate of modern sector employment $L_{2}^{*}$. Workers will have shifted from the rural economy to the modern sector. As depicted in Fig. 5, the outcome generates a self-reinforcing process of growth and labor absorption. Positive growth in the modern sector implies that its capital-labor ratio is rising, and any corresponding increase in capital will shift out the marginal productivity curve for labor. More workers will transfer from the rural economy to the modern sector, and the growth rate $\gamma$ will increase further. This self-reinforcing process ensures that the land surplus rural economy will shrink, and the modern sector expands, until eventually a fully modern economy will emerge.

This outcome is in accord with the industrial and structural transformation policies that are frequently advocated to encourage modern sector growth in developing economies, and especially in Latin America and the Caribbean (Lin 2011; McMillan and Rodrik 2011; Ocampo et al. 2009; Rodrik 2007, 2010). For example, as argued by Rodrik (2010, p. 90), "all successful countries have followed what one might call 'productivist' policies. These are activist policies aimed at enhancing the profitability of modern industrial activities and accelerating the movement of resources towards modern industrial activities", which include explicit industrial policies such as "tax and credit incentives" for investment. ${ }^{3}$

\footnotetext{
3 As outlined by Rodrik (2007, pp. 117-118), government could implement a broad range of incentive programs, including subsidizing costs of "self discovery" of profitable new products, developing mechanisms for higher-risk finance, internalizing coordination externalities, public R\&D, subsidizing general technical training, and taking advantage of national abroad.
} 
Similarly, Ocampo et al. (2009, p. 132) maintain that, where successful, the overall goal for industrial and credit policies in developing economies has been "to induce firms 'to learn' or acquire 'specific assets' ...with the objective of building up technically advanced productive capacity."

\section{Targeted policies for traditional agriculture on marginal land}

However, even if targeted policies in the modern sector succeed in raising the productivity of labor in that sector, the rising productivity does not translate into higher real wages for labor. The reason has to do with the key structural feature of the land surplus rural economy; as long as there remains significant numbers of the rural population farming marginal land, the Ricardian surplus land condition (15) ensures that the unchanging land-labor ratio for traditional agriculture on less favored land will determine the nominal wage rate for all sectors of the economy. Thus, as shown in Fig. 5, although workers will shift from the rural economy to the modern sector, they will not necessarily be better off. Although eventually when a fully modern economy occurs, all workers will be paid their marginal productivity. However, in the transition to that outcome, with significant numbers of rural households still located in marginal areas, there may be a need for targeted policies to these households to raise real wages and alleviate widespread rural poverty.

The introduction of new inputs, such as fertilizers or improved varieties, and other technical improvements on marginal land may be neutral, or biased in favor of either land or labor. But if any such technical progress fails to affect the zero marginal productivity condition indicated in (15), then the land-labor ratio for production on marginal land must, therefore, remain the same. However, the average productivity of labor $g\left(n_{2}^{m}\right)$ can rise as a result of technical improvements on marginal land, and if that is the case, real wages $w / p_{2}$ will increase. Since $p_{2}$ is fixed, this implies a rise in the nominal wage.

As shown in Fig. 5, an increase in the nominal wage for the entire economy has the effect of shifting up the straight line represented by $p^{m} g\left(n^{m}\right)=w$. As condition (17) indicates, there will be a new labor market equilibrium. However, as depicted in Fig. 5, if there are targeted modern sector policies in place, the implications of this new equilibrium will be different for the primary production as opposed to the modern sector.

The rise in the nominal wage leads to an increase in real wages $w / p_{1}$ in commercial primary production activities. Labor employment $L_{1}$ declines and the resource-labor ratio increases. From (12), $N_{1}$ must also decrease as employment in primary production falls. However, in order for $n_{1}$ to rise, $L_{1}$ must decline more than $N_{1}$. Thus, the effect of technical progress on marginal land and the consequent rise in wages is a contraction in export-oriented primary production and employment.

Without modern sector expansion, there should also be contraction in employment in this sector, too. However, as outlined in the previous section and illustrated in Fig. 5, targeted policies for the modern sector will cause the marginal productivity of labor (the $p_{2} K_{2} \tilde{h}^{\prime}\left(L_{2}\right)$ curve in Fig. 5) to shift out, and thus some 
increase in $L_{2}$. This will lead to positive growth in the modern sector and a rising capital-labor ratio, which means that the resulting increase in capital will cause the marginal productivity curve for labor to shift out continuously. Although as shown in Fig. 5 rising nominal and real wages may reduce some of the labor absorption caused by the expanding modern sector, as long as the productivity curve for $L_{2}$ shifts out, there will be some labor absorption by the sector. Eventually the selfreinforcing process of increasing growth, capital investment and labor employment in the modern sector will induce more workers to transfer from the rural economy to the modern sector, and the growth rate $\gamma$ will increase further.

The self-reinforcing process of dynamic growth in the modern sector ensures once again that the land surplus rural economy will shrink, and modern production activities expand, until eventually a fully modern economy will emerge. ${ }^{4}$ However, by targeting investments and policies to improve the livelihoods and productivity of traditional agriculture on marginal land, this process leads to higher real wages and reductions in rural poverty in the interim period before the emergence of the fully modern economy.

Such an outcome supports recent efforts to target investments directly to improve the livelihoods of the rural populations in remote and fragile environments (World Bank 2008). For example, in Ecuador poverty maps have been developed to target public investments to geographically defined sub-groups of the population according to their relative poverty status, which could substantially improve the performance of the programs in term of poverty alleviation (Elbers et al. 2007). A World Bank study that examined 122 targeted programs in 48 developing countries confirms their effectiveness in reducing poverty, if they are designed properly (Coady et al. 2004). The benefits are even larger when programs, such as PROGRESA in Mexico, were successful in employing second-round targeting to identify households in less favored locations and thus reducing leakages to non-poor households (Higgins et al. 2010, p. 20).

Appropriate targeting of research, extension and agricultural development has been shown to improve the livelihoods of the poor, increase employment opportunities and even reduce environmental degradation (Barbier 2010, 2012; Carr 2009a, b; CavigliaHarris and Harris 2008; Coxhead et al. 2002). Empirical evidence of technical change, increased public investments and improved extension services in remote regions indicates that any resulting land improvements that do increase the value of homesteads can have a positive effect on both land rents and reducing agricultural expansion (Bellon et al. 2005; Coxhead et al. 2002; Sills and Caviglia-Harris 2008).

Improving market integration for the rural poor may also depend on targeted investments in a range of public services and infrastructure in remote and ecologically fragile regions, such as extension services, roads, communications, protection of property, marketing services and other strategies to improve smallholder accessibility to larger markets (World Bank 2008). Targeting

\footnotetext{
${ }^{4}$ Note that Fig. 5 depicts an interim period where residual labor still has to be absorbed on marginal land. Although modern sector employment has expanded, it cannot absorb all the labor released from primary production. Some of the resulting unemployed labor must, therefore, be absorbed through greater traditional agricultural cultivation of marginal land. As $L_{2}^{m}$ increases, $N_{2}^{m}$ must rise proportionately in order to keep the land-labor ratio fixed.
} 
agricultural research and extension services to poor farmers combined with investments in rural road infrastructure to improve market access appears to generate positive development and poverty alleviation benefits (Bellon et al. 2005; Pattanayak et al. 2003). For example, in Mexico, poverty mapping was found to enhance the targeting of maize crop breeding efforts to poor rural communities in less favorable and remote areas (Bellon et al. 2005).

\section{Empirical evidence}

The dual economy model with surplus rural land yields two predictions. First, the concentration of rural populations on less favored agricultural land is a barometer of economy-wide development. Economies with a larger share of their rural populations on marginal land are likely to be developing less rapidly and thus display lower rates of long-run economic growth compared to economies with smaller concentrations of rural households on this type of land. On the other hand, economies with a greater share of their workforce employed in industry and other modern sector activities are likely to develop more rapidly, and hence have higher rates of long-run economic growth. Both of these predictions are examined empirically for the economies of Latin America and Caribbean.

The estimation to test these predictions is based on the standard empirical neoclassical growth framework for conditional convergence. This approach relates the real per capita growth rate over a given period to an initial level of per capita real gross domestic product (GDP), plus a variety of control and environmental variables representing international openness, governance, and prevailing human, physical and natural capital endowments (Barro and Sala-I-Martin 2004). These factors have been found to influence long-term growth in Latin America since 1900 (Astorga 2010). The possible endogeneity of these explanatory variables was taken into account using lagged values as instruments. For each variable, the instrument consists of the average over 5 years preceding 1990. The exceptions include (log) per capita real GDP in 1990, the governance variables, which were averaged over 1996-2011, and the dummy variable for small island developing states. The governance variables are from the Worldwide Governance Indicators (Kaufmann et al. 2010), the UN classification of small island developing states was employed to create the dummy variable (see http:// www.un.org/special-rep/ohrlls/sid/list.htm), and the remaining variables are from the World Development Indicators (World Bank 2013).

To test the predictions of the model of this paper, the growth analysis is further extended to include the share of the rural population concentrated on less favored agricultural land and the share of the workforce employed in industry as additional explanatory variables. ${ }^{5}$ The latter variable is from World Bank (2013), averaged over the 5 years preceding 1990 to avoid endogeneity problems.

\footnotetext{
${ }^{5}$ To test the possibility that booms and busts in primary products trade may impact, at least temporarily, an economy's overall development, the share of primary products in total merchandise exports was also added as an explanatory variable in different versions of the growth analysis. However, the estimated coefficient of this variable is insignificant, and its inclusion does not improve the robustness of the estimation.
} 
Less favored agricultural land consists of irrigated land on terrain greater than $8 \%$ median slope; rainfed land with a length of growing period (LGP) of more than 120 days but either on terrain greater than $8 \%$ median slope or with poor soil quality; semi-arid land (land with LGP 60-119 days); and arid land (land with LGP $<60-119$ days). These various land areas were determined by employing in Arc GIS 10.1 the datasets from the FAO Global Agro-Ecological Zones (GAEZ) Data Portal version 3 (Available online: http://gaez.fao.org/) combined with national boundaries from the Gridded Population of the World, Version 3 (GPWv3) of the Center for International Earth Science Information Network (CIESIN) and Centro Internacional de Agricultura Tropical (CIAT). Agricultural land (\% of land area) data were obtained from the World Development Indicators (World Bank 2013), and rural populations determined from the rural-urban extent dataset that was published as part of CIESIN Global Rural Urban Mapping Project (GRUMPv1). Use of these spatial datasets enabled the measurement of the share of rural population on less favored agricultural land for the 35 LAC countries in 2000, the midpoint of the 1990-2011 estimation period. ${ }^{6}$

Because a lagged value for years preceding 1990 could not be created for the share of rural population on marginal land, this variable is likely to be endogenous in the regression for average annual growth over 1990-2011. OLS regression and the consequent Hausman specification test for simultaneity confirms at the $5 \%$ significance level the possibility of endogeneity. The instrumental variables threestage least squares (3SLS) estimation is used to correct for this problem. In this procedure, it is assumed that the structural system includes both the growth regression and a second equation for the share of rural population on less favored agricultural land. Based on the insights of the theoretical model, the explanatory variables in the latter equation are factors that explain the prominence of an agricultural-based rather than a modern economy: arable land per capita, gross fixed capital formation as a percentage of GDP, agricultural value added as a share of GDP and the small island developing states dummy. In the 3SLS procedure, the instruments of the first stage include all the exogenous variables of the two structural equations. Three additional exogenous instruments, also averaged over 5 years preceding 1990, were also included: primary school enrolment rate, secondary school enrolment rate and land area. The second and third stages involve the seemingly unrelated linear regression equations (SURE) procedure, employing two-step (or iterative) feasible generalized least square (GLS) that accounts for contemporaneous correlation in the errors across equations.

The analysis was conducted for long-term annual average growth over the 1990-2011 period for the 35 LAC economies listed in Table $1 .^{7}$ The final 3SLS

\footnotetext{
${ }^{6}$ I am grateful to Jacob P. Hochard for assistance in determining this variable. The spatial data sets allowed estimates of the percentage of the rural population on less favored agricultural land for 2000 , 2005 and 2010. The 2010 estimate was employed in Table 1 . The 2000 estimate was used in the long-run grown regression as it is the mid-point over the 1990-2011 time period of the regression.

${ }^{7}$ Although other governance indicators from the Worldwide Governance Indicators, such as control of corruption, government effectiveness, regulatory quality, rule of law, and voice and accountability, were employed in the estimation, political stability and absence of violence were the most consistently significant variable in the long-run growth estimation. Unfortunately, collinearity problems prevented the inclusion of more than one governance indicator in the regression.
} 
Table 2 3SLS estimation of long-run growth, Latin America and Caribbean, 1990-2011

\begin{tabular}{|c|c|c|}
\hline & $\begin{array}{l}\text { Average annual real GDP per } \\
\text { capita growth, 1990-2011 } \\
(N=35)^{\mathrm{a}}\end{array}$ & $\begin{array}{l}\% \text { of rural population on less } \\
\text { favored agricultural land, } 2000 \\
(N=35)\end{array}$ \\
\hline Constant & $9.0298(4.081)^{* *}$ & $42.894(5.207)^{* *}$ \\
\hline Log real GDP per capita, 1990 & $-1.0038(-4.118)^{* *}$ & \\
\hline $\begin{array}{l}\% \text { of rural population on less favored } \\
\text { agricultural land, } 2000\end{array}$ & $-0.0554(-2.334)^{*}$ & \\
\hline $\begin{array}{l}\text { Employment in industry (\% of total } \\
\text { employment), average over } 5 \text { years } \\
\text { preceding } 1990\end{array}$ & $0.1197(3.324)^{* *}$ & \\
\hline $\begin{array}{l}\text { Arable land (ha) per capita, average } \\
\text { over } 5 \text { years preceding } 1990\end{array}$ & & $-10.017(-0.747)$ \\
\hline $\begin{array}{l}\text { Gross fixed capital formation ( } \% \text { of } \\
\text { GDP), average over } 5 \text { years } \\
\text { preceding } 1990\end{array}$ & $0.0001(0.073)$ & $-0.5884(-2.055)^{*}$ \\
\hline $\begin{array}{l}\text { Trade openness (exports }+ \text { imports } \% \\
\text { of GDP), average over } 5 \text { years } \\
\text { preceding } 1990\end{array}$ & $0.0020(0.406)$ & \\
\hline $\begin{array}{l}\text { Population growth, average over } \\
5 \text { years preceding } 1990\end{array}$ & $-0.0020(-0.011)$ & \\
\hline $\begin{array}{l}\text { Agricultural value added (\% of GDP), } \\
\text { average over } 5 \text { years preceding } 1990\end{array}$ & & $0.5542(1.921)^{*}$ \\
\hline $\begin{array}{l}\text { Political stability and absence of } \\
\text { violence/terrorism, 1996-2011 } \\
\text { average }\end{array}$ & $0.7724(2.457) *$ & \\
\hline $\begin{array}{l}\text { Dummy for small island developing } \\
\text { states }\end{array}$ & $-1.0322(-1.848) \#$ & $-13.936(-2.205)^{*}$ \\
\hline Likelihood ratio test $(\beta=0)$ & $26.10^{* *}$ & $22.42 * *$ \\
\hline Akaike information criterion (AIC) & 0.1006 & 5.3613 \\
\hline Amemiya prediction criterion (APC) & 0.1124 & 5.3647 \\
\hline
\end{tabular}

* Significant at $95 \%$ level

** Significant at $99 \%$ level

\# Significant at $90 \%$ level

${ }^{a}$ Mean is $1.8 \%$ and median is $1.7 \% ; t$ statistics are indicated in parentheses

${ }^{\mathrm{b}}$ Mean is $26.9 \%$ and median is $24.9 \%$; $t$ statistics are indicated in parentheses. Instruments are the constant, GDP per capita in 1990, employment in industry, arable land per capita, gross fixed capital formation, openness, population growth, agricultural value added, political stability, dummy for small island developing states, primary school enrolment, secondary school enrolment and land area

regression results for long-run growth for LAC economies and the percentage of rural population on less favored agricultural land are depicted in Table 2. Average annual growth over 1990-2011 is significantly reduced across LAC countries as the share of rural population on marginal land increases. On the other hand, economies with a greater share of employment in industry display on average higher long-run growth. These results seem to confirm the two main predictions of the dual economy model. 
Both agricultural value added and investment share of GDP appear to have an indirect impact on long-run growth via the concentration of rural population on marginal land. Gross fixed capital formation as a percentage of GDP seems to reduce this concentration, which translates into a positive influence on long-run growth. However, a higher share of agriculture in GDP leads to more rural people located on less favored agricultural land, which reduces long-run growth. Small island developing states appear to have less people on marginal land, which is good for growth, but these economies also display lower long-run growth rates compared to other LAC countries. Political stability and absence of violence or terrorism is correlated with higher growth in Latin America and the Caribbean.

Finally, the empirical results also show that the concentration of rural populations on marginal land and the industrial share of total employment have an important influence on how fast each LAC economy "converges" to its long-run steady state. Table 2 indicates that the growth path of LAC economies displays conditional convergence. That is, growth over 1990-2011 is inversely related to the initial level of real GDP per capita in 1990. However, this relationship is clearly conditioned on how much of the rural population is concentrated on less favored agricultural land and on the share of industry in total employment.

\section{Conclusion}

The model of this paper is based on two important stylized facts concerning the rural sector of LAC economies. First, many economies have a "residual" pool of rural poor located on abundant but less favored agricultural land, and second, considerable land use conversion and resource exploitation are occurring through expansion of a commercial primary products sector. These Ricardian land surplus conditions can lead to a permanent "dualistic" outcome in the economy, where the modern sector competes with the commercial primary production sector for available labor, with marginal land absorbing the residual. In addition, the economy is vulnerable to primary product price booms and productivity increases, which will cause manufacturing employment and output to contract while the primary sector expands, until complete specialization occurs.

The empirical analysis of long-run growth over 1990-2011 for 35 LAC economies confirms two predictions of the model. As the share of rural population on less favored agricultural land increases, long-run growth diminishes. In contrast, a greater share of employment in industry is consistent with higher longrun growth.

As the paper has shown, avoiding some of the negative outcomes predicted by the dual economy model can occur through implementing targeted modern sector policies, as suggested by some (Lin 2011; McMillan and Rodrik 2011; Ocampo et al. 2009; Rodrik 2007, 2010). However, even if such policies succeed in raising the productivity of modern sector workers, the rising productivity does not translate into higher real wages for labor. Moreover, before the emergence of the fully modernized economy, there is likely to be an interim period during which poor rural households will remain on marginal land. As long as this residual pool of labor 
exists, workers shifting from the rural economy to the modern sector will not necessarily be better off. During this transition period, targeted policies are required to raise real wages and alleviate widespread rural poverty in marginal areas. Such policies include investments to improve the livelihoods of the rural poor in remote and fragile environments, appropriate research, extension and agricultural development for marginal land, and better market integration through extension service, roads, communication, protection of property, marketing services and other strategies to improve smallholder accessibility to larger markets.

Any policy strategy targeted at improving the livelihoods of the rural poor located in remote and fragile environments should be assessed against an alternative strategy, which is to encourage greater out-migration from these areas. As pointed out by Lall et al. (2006, p. 48), rural development is essentially an indirect way of deterring migration to cities, yet because of the costliness of rural investments, "policies in developing countries are increasingly more concerned with influencing the direction of rural to urban migration flows-e.g. to particular areas-with the implicit understanding that migration will occur anyway and thus should be accommodated at as low a cost as possible." Rarely, however, are the two types of policy strategies, investment in poor rural areas and targeted out-migration, directly compared. In addition, only recently the linkages between rural out-migration, smallholder agriculture and land use change and degradation in remote and marginal areas have been analyzed (Mendola 2008, 2012; Gray 2009; Greiner and Sakdapolrak 2013; VanWey et al. 2012). Researching such linkages will become increasingly important to understand the conditions under which policies to encourage greater rural out-migration should be preferred to a targeted strategy to overcome poverty in remote and fragile areas. It may be, as argued by the World Bank (2008, p. 49), that "until migration provides alternative opportunities, the challenge is to improve the stability and resilience of livelihoods in these regions". As this paper has pointed out, this may become a critical feature in the design of structural transformation policies to overcome widespread rural poverty in many LAC economies.

Acknowledgments I am grateful for comments by David R. Heres, Jacob P. Hochard, Juan Rosellon and an anonymous referee.

Open Access This article is distributed under the terms of the Creative Commons Attribution License which permits any use, distribution, and reproduction in any medium, provided the original author(s) and the source are credited.

\section{Appendix: Growth dynamics in the modern sector}

\section{Decentralized solution}

In the decentralized economy, decisions are made by competitive firms and households. It is assumed that the representative household has the choice to work either in the modern sector or in commercial primary production. 
Households employed in traditional agriculture on less favored land consume all production within that sector and do not accumulate assets. Thus, the relevant population that the representative household comprises $L_{1}+L_{2}$. With no population growth and free labor mobility, this population is determined by the labor market equilibrium, which is in turn based on the predetermined nominal wage $w$ in the economy (from condition 5). Hence, if $M$ is known, then per capita imports are also determined exogenously to the household's welfare-maximizing decision.

The representative household seeks to

$$
\begin{gathered}
\underset{c(t)}{\operatorname{Max}_{x} U}=\int_{0}^{\infty}\left[\frac{\left(c(t)^{1-\theta}+m^{1-\theta}\right)-1}{1-\theta}\right] e^{-\rho t} \mathrm{~d} t \\
\text { s.t. } \dot{a}=r a+w-c, \quad a(0)=a_{0},
\end{gathered}
$$

which yields the following optimization and transversality conditions, respectively

$$
\begin{gathered}
\frac{\dot{c}}{c}=\frac{1}{\theta}(r-\rho) \\
\lim _{t \rightarrow \infty} a(t) e^{-\int_{0}^{t} r v \mathrm{~d} v}=0 .
\end{gathered}
$$

Setting $a=k_{2}$ in (18), and using the marginal productivity conditions (7) and (8) to substitute for $r$ and $w$, yields

$$
\dot{k}_{2}=p_{2}\left[\tilde{h}\left(L_{2}\right)-L_{2} \tilde{h}^{\prime}\left(L_{2}\right)\right] k_{2}+p_{2} K_{2} \tilde{h}^{\prime}\left(L_{2}\right)-c=p_{2} \tilde{h}\left(L_{2}\right) k_{2}-c,
$$

which is condition (11) for the accumulation of capital per person in the economy.

Similarly, using (7) in (19)

$$
\frac{\dot{c}}{c}=\frac{1}{\theta}\left(p_{2}\left[\tilde{h}\left(L_{2}\right)-L_{2} \tilde{h}^{\prime}\left(L_{2}\right)\right]-\rho\right) \equiv \gamma .
$$

Condition (22) defines the consumption growth path of the decentralized economy of the modern sector, which is constant if $L_{2}$ is unchanging, and is positive if $p_{2}\left[\tilde{h}\left(L_{2}\right)-L_{2} \tilde{h}^{\prime}\left(L_{2}\right)\right]>\rho$. If $\gamma$ is constant, then the per capita consumption path is $c(t)=c(0) e^{\gamma t}$. Substituting the latter expression into (17) gives

$$
U=\int_{0}^{\infty}\left[\frac{c(0)^{1-\theta} e^{(1-\theta) \gamma t}+m^{1-\theta}-1}{1-\theta}\right] e^{-\rho t} \mathrm{~d} t .
$$

The integral (23) will converge to infinity unless $\rho>(1-\theta) \gamma$, which along with (22), implies that $\dot{c} / c=\gamma>0$ iff

$$
p_{2}\left[\tilde{h}\left(L_{2}\right)-L_{2} \tilde{h}^{\prime}\left(L_{2}\right)\right]>\rho>\frac{1-\theta}{\theta}\left(p_{2}\left[\tilde{h}\left(L_{2}\right)-L_{2} \tilde{h}^{\prime}\left(L_{2}\right)\right]-\rho\right) .
$$

Substituting $c(t)=c(0) e^{\gamma t}$ into (21) yields $\dot{k}_{2}=p_{2} \tilde{h}\left(L_{2}\right) k_{2}-c(0) e^{\gamma t}$. Letting $\beta=p_{2} \tilde{h}\left(L_{2}\right)$, the solution to this differential equation for capital per person is 


$$
k_{2}(t)=\mathrm{be}^{\beta t}+\frac{c(0)}{\varphi} e^{\gamma t}, \quad \varphi=\beta-\gamma=p_{2} \tilde{h}\left(L_{2}\right)-\gamma,
$$

where $b$ is an unknown constant. Condition (24) implies that $\varphi>0$.

Using $a=k_{2}$ and (25) in the transversality condition (20)

$$
\lim _{t \rightarrow \infty} k_{2}(t)=\lim _{t \rightarrow \infty}\left\{\mathrm{be}^{(\beta-r) t}+\frac{c(0)}{\varphi} e^{(\gamma-r) t}\right\}=0
$$

From (25) and (7), it is clear that $\beta-r=-L_{2} \tilde{h}^{\prime}\left(L_{2}\right)<0$, which indicates that $e^{(\beta-r) t}$ in (26) converges to one. From (22) and (7), $\gamma-r=\frac{1-\theta}{\theta} p_{2}\left[\tilde{h}\left(L_{2}\right)-L_{2} \tilde{h}^{\prime}\left(L_{2}\right)\right]-\frac{\rho}{\theta}$, which from the lower bound on convergence in condition (24) implies that $\gamma-r<0$. As $c(0)$ is finite and $\varphi>0$, the second term inside the curly brackets in (26) converges toward zero. Hence, the transversality condition (26) requires the constant $b$ to be zero. Equation (25), therefore, implies

$$
c(t)=\varphi k_{2}(t), \quad \varphi=p_{2} \tilde{h}\left(L_{2}\right)-\gamma,
$$

which is the same as (12) in the text. Along the path of the decentralized modern sector, consumption per capita is proportional to capital per person. Given that $q_{2}=\tilde{h}\left(L_{2}\right) k_{2}$, then it follows that

$$
\frac{\dot{q}_{2}}{q_{2}}=\frac{\dot{k}_{2}}{k_{2}}=\frac{\dot{c}}{c}=\gamma, \quad \gamma=\frac{1}{\theta}\left(p_{2}\left[\tilde{h}\left(L_{2}\right)-L_{2} \tilde{h}^{\prime}\left(L_{2}\right)\right]-\rho\right),
$$

which is (13) in the text. Per capita consumption, capital and output grow at the same rate in the decentralized economy of the modern sector.

\section{Optimal solution}

Unlike an individual producer, a benevolent social planner takes into account that each firm's increase in its capital stock adds to the aggregate capital of the modern sector via knowledge spillovers. That is, the social planner solves for (17) with respect to (21) and $k(0)=k_{0}$, which yields the following optimization and transversality conditions

$$
\frac{\dot{c}}{c}=\frac{1}{\theta}\left(p_{2} \tilde{h}\left(L_{2}\right)-\rho\right) \equiv \gamma^{*}, \lim _{t \rightarrow \infty} k(t) e^{-\int_{0}^{t} r v \mathrm{~d} v}=0 .
$$

Condition (29) indicates that the optimal consumption growth path of the economy is constant if $L_{2}$ is unchanging, and is positive if $p_{2} \tilde{h}\left(L_{2}\right)>\rho$. If $\gamma^{*}$ is constant, then the optimal per capita consumption path is $c(t)=c(0) e^{\gamma^{*} t}$. This result implies that the integral (23) will converge to infinity unless $\rho>(1-\theta) \gamma^{*}$, which along with (29), implies that $\dot{c} / c=\gamma>0$ iff

$$
p_{2} \tilde{h}\left(L_{2}\right)>\rho>\frac{1-\theta}{\theta}\left(p_{2} \tilde{h}\left(L_{2}\right)-\rho\right) .
$$


Following the same method as for the decentralized economy of the modern sector, solution to (21) is

$$
k_{2}(t)=b e^{\beta t}+\frac{c(0)}{\varphi^{*}} e^{\gamma * t}, \quad \varphi^{*}=\beta-\gamma^{*}=p_{2} \tilde{h}\left(L_{2}\right)-\gamma^{*}
$$

Condition (30) implies that $\varphi^{*}>0$ and the transversality condition in (29) ensures that $b=0$. It, therefore, follows from (31) that

$$
c(t)=\varphi^{*} k_{2}(t), \quad \varphi^{*}=p_{2} \tilde{h}\left(L_{2}\right)-\gamma^{*} .
$$

Along the optimal path for the modern sector, consumption per capita is proportional to capital per person. As $q_{2}=\tilde{h}\left(L_{2}\right) k_{2}$, then it follows that optimal modern sector growth is determined by

$$
\frac{\dot{q}_{2}}{q_{2}}=\frac{\dot{k}_{2}}{k_{2}}=\frac{\dot{c}}{c}=\gamma^{*}, \quad \gamma^{*}=\frac{1}{\theta}\left(p_{2} \tilde{h}\left(L_{2}^{*}\right)-\rho\right),
$$

which is (16) in the text. Optimal growth of per capita consumption, capital and output occurs at the same rate in the modern sector, and the magnitude of this growth rate is determined by total employment in the sector $L_{2}^{*}$. As $\gamma^{*}>\gamma$, the optimal growth of the modern sector exceeds growth in the sector based solely on the decentralized decisions of consumers and firms. Because the social planner takes into account learning-by-doing and knowledge spillovers across the sector, the optimal growth rate is determined in accordance with the average product of capital $\tilde{h}\left(L_{2}^{*}\right)$ whereas the decentralized solution takes into account only the private marginal product of capital $\tilde{h}\left(L_{2}\right)-L_{2} \tilde{h}^{\prime}\left(L_{2}\right)$. Thus, the growth rate generated by decentralized decision making in the modern sector is too low.

The decentralized economy of the modern sector can still attain the optimal growth rate $\gamma^{*}$ if capital goods purchased by individual producers are subsidized. For example, suppose that producers receive a subsidy on interest payments equivalent to $s=p_{2} L_{2}^{*} \tilde{h}^{\prime}\left(L_{2}^{*}\right)$. From (7), the private marginal productivity of capital would be $p_{2}\left[\tilde{h}\left(L_{2}\right)-L_{2} \tilde{h}^{\prime}\left(L_{2}\right)\right]=r-s$, which would ensure that in (13) the decentralized and optimal growth rate would be the same $\gamma=\gamma^{*}=\frac{1}{\theta}\left(p_{2} \tilde{h}\left(L_{2}^{*}\right)-\rho\right)$. If the subsidy is funded through a lump sum tax on the wages received by consumers $s=\tau w$, then the budget constraint (18) of the representative consumer becomes $\dot{a}=r a+(1-\tau) w-c$. However, maximization of utility (17) with respect to this new constraint does not change the optimization condition (19). Thus, taxing consumer wages to pay for the subsidy for capital purchases by producers does not introduce any distortion in the model of the modern sector.

\section{References}

Aide TM, Clark ML, Grau HR, López-Carr D, Levy MA, Redo D, Bonilla-Moheno M, Riner G, AndradeNúñez MJ, Muñiz M (2013) Deforestation and reforestation of Latin America and the Caribbean (2001-2010). Biotropica 45:262-271 
Aldrich S, Walker R, Arima E, Caldas M (2006) Land-cover and land-use change in the Brazlian Amazon: smallholders, ranchers, and frontier stratification. Econ Geogr 82:265-288

Astorga P (2010) A century of growth in Latin America. J Dev Econ 92:232-243

Banerjee AV, Duflo E (2007) The economic lives of the poor. J Econ Perspect 21(1):141-168

Barbier EB (2004) Agricultural expansion, resource booms and growth in Latin America: implications for long-run economic development. World Dev 32:137-157

Barbier EB (2005) Natural resources and economic development. Cambridge University Press, Cambridge

Barbier EB (2010) Poverty, development and environment. Environ Dev Econ 15:635-660

Barbier EB (2011) Scarcity and frontiers: how economies have developed through natural resource exploitation. Cambridge University Press, Cambridge

Barbier EB (2012) Natural capital, ecological scarcity and rural poverty. In: Policy research working paper no. 6232. The World Bank, Washington, DC

Barbier EB (2013) Structural change, dualism and economics development: the role of the vulnerable poor on marginal lands.In: Policy research working paper no. 6456. The World Bank, Washington, $\mathrm{DC}$

Barbier EB (in press) Land use and sustainable economic development: developing world. Chapter 16. In: Duke JM, Wu J (eds) The oxford handbook of land economics. Oxford University Press, Oxford

Barro RJ, Sala-I-Martin X (2004) Economic growth, 2nd edn. MIT Press, Cambridge

Bellon MR, Hodson D, Bergvinson D, Beck D, Martinez-Romero E, Montoya Y (2005) Targeting agricultural research to benefit poor farmers: relating poverty mapping to maize environments in Mexico. Food Policy 30:476-492

Borras SM, Franco JC, Gómez S, Kay C, Spoor M (2012) Land grabbing in Latin America and the Caribbean. J Peasant Stud 39:845-872

Boucher D, Elias P, Lininger K, May-Tobin C, Roquemore S, Saxon E (2011) The root of the problem: What's driving tropical deforestation today?. Union of Concerned Scientists, Cambridge

Bridge G (2008) Global production networks and the extractive sector: governing resource-based development. J Econ Geogr 8:389-419

Browder J, Pedlowski M, Walker R, Wynne R, Summers P, Abad A, Becerra-Cordoba N, Mil-Homens J (2008) Revisiting theories of frontier expansion in the Brazilian Amazon: a survey of colonist farming population in Rondônia's post-frontier, 1992-2002. World Dev 36:1469-1492

Carr D (2009a) Population and deforestation: why rural migration matters. Prog Hum Geogr 33:355-378

Carr D (2009b) Population and deforestation: why rural migration matters. Prog Hum Geogr 33:355-378

Caviglia-Harris JL, Harris D (2008) Integrating survey and remote sensing data to analyze land use scale: insights from agricultural households in the Brazilian Amazon. Int Reg Sci Rev 31:115-137

Caviglia-Harris J, Sills EO, Mullan K (2013) Migration and mobility on the Amazon frontier. Popul Environ 34:338-369

Chomitz K, Buys P, De Luca G, Thomas T, Wertz-Kanounnikoff S (2007) At loggerheads? Agricultural expansion, poverty reduction, and environment in the tropical forests. The World Bank, Washington, DC

Chronic Poverty Research Centre (CPRC) (2004) Chronic poverty report 2004-5. CPRC, University of Manchester, Manchester

Coady D, Grosh M, Hoddinott J (2004) Targeting outcomes redux. World Bank Res Obs 19(1):61-85

Comprehensive Assessment of Water Management in Agriculture (2007) Water for food, water for life: a comprehensive assessment of water management in agriculture. Earthscan and International Water Management Institute, Colombo, Sri Lanka, London

Coxhead I, Shively GE, Shuai X (2002) Development policies, resource constraints, and agricultural expansion on the Philippine land frontier. Environ Dev Econ 7:341-364

DeFries R, Rudel T, Uriarte M, Hansen M (2010) Deforestation driven by urban population growth and agricultural trade in the twenty-first century. Nat Geosci 3:178-801

Deininger K, Byerlee D (2012) The rise of large farms in land abundant countries: do they have a future? World Dev 40:701-714

Domar E (1970) The causes of slavery or serfdom: a hypothesis. J Econ Hist 30(1):18-32

Elbers C, Fujii T, Lanjouw P, Özler B, Yin W (2007) Poverty alleviation through geographic targeting: how much does disaggregation help? J Dev Econ 83:198-213

Etter A, McAlpine C, Possingham H (2008) Historical patterns and drivers of landscape change in Colombia since 1500: a regionalized spatial approach. Ann Assoc Am Geogr 98:2-23 
Food and Agricultural Organization (FAO) of the United Nations (2006) Global forest resources assessment 2005, main report. Progress towards sustainable forest management. FAO Forestry paper 147. FAO, Rome

Gibbs HK, Ruesch AS, Achard F, Clayton MK, Holmgren P, Ramankutty N, Foley JA (2010) Tropical forests were the primary sources of new agricultural lands in the $1980 \mathrm{~s}$ and $1990 \mathrm{~s}$. Proc Natl Acad Sci 107:16732-16737

Gray CL (2009) Rural out-migration and smallholder agriculture in the southern Ecuadorian Andes. Popul Environ 30:193-217

Greiner C, Sakdapolrak P (2013) Rural-urban migration, agrarian change, and the environment in Kenya: a critical review of the literature. Popul Environ 34(4):524-533

Hansen B (1979) Colonial economic development with unlimited supply of land: a Ricardian case. Econ Dev Cult Chang 27(4):611-627

Higgins K, Bird K, Harris D (2010) Policy responses to the spatial dimensions of poverty. ODI working paper 328. Overseas Development Institute, London

International Fund for Agricultural Development (IFAD) (2010) Rural poverty report 2011. New realities, new challenges: new opportunities for tomorrow's generation. IFAD, Rome

Jalan J, Ravallion M (1997) Spatial poverty traps? Policy research working paper 1798. World Bank, Washington, DC

Jiménez JP, Tromben V (2006) Fiscal policy and the commodities boom: the impact of higher prices for non-renewables in Latin America and the Caribbean. CEPAL Rev 90:59-84

Kaufmann D, Kraay A, Mastruzzi M (2010) The worldwide governance indicators: methodology and analytical issues. Policy research working paper no. 5430. The World Bank, Washington, DC

Lall SV, Selod H, Shalizi Z (2006) Rural-urban migration in developing countries: a survey of theoretical predictions and empirical findings. World bank policy research working paper 3915, May 2006. The World Bank, Washington, DC

Lambin EF, Meyfroidt P (2011) Global land use change, economic globalization, and the looming land scarcity. Proc Natl Acad Sci 108:3465-3472

Lin JY (2011) New structural economics: a framework for rethinking development. World Bank Res Obs 26:193-221

López RE (2003) The policy roots of socioeconomic stagnation and environmental implosion: Latin America 1950-2000. World Dev 31(2):259-280

Maloney WF (2002) Missed opportunities: innovation and resource-based growth in Latin America. Economia 3:111-167

Mann ML, Kaufmann RK, Bauer D, Gopal S, Del Carmen Vera-Diaz M, Nepstad D, Merry F, Kallay J, Amacher GS (2010) The economics of cropland conversion in Amazonia: the importance of agricultural rent. Ecol Econ 69:1503-1509

Matsuyama K (1992) Agricultural productivity, comparative advantage, and economic growth. J Econ Theory 58:317-334

McMillan M, Rodrik D (2011) Globalization, structural change, and productivity growth. NBER working paper no. 17143. National Bureau of Economic Research, Boston, MA

Mendola M (2008) Migration and technological change in rural households: complements or substitutes? J Dev Econ 85:150-175

Mendola M (2012) Review Article: rural out-migration and economic development at origin: a review of the evidence. J Int Dev 24:102-122

Mueller B (1997) Property rights and the evolution of the a frontier. Land Econ 73:42-57

Ocampo JA, Rada C, Taylor L (2009) Growth and policy in developing countries: a structuralist approach. Columbia University Press, New York

Pacheco P, Aguilar-Støen M, Börner J, Etter A, Putzel L, del Carmen Vera Diaz M (2011) Landscape transformation in tropical Latin America: assessing trends and policy implications for REDD+. Forests 2:1-29

Pattanayak SK, Mercer DE, Sills E, Yang J-C (2003) Taking stock of agroforestry adoption studies. Agrofor Syst 57:173-186

Pichón F (1997) Colonist land-allocation decisions, land use, and deforestation in the Ecuadorian frontier Economic. Dev Cult Chang 45:707-744

Rodrigues A, Ewers R, Parry L, Souza C, Verissimo A, Balmford A (2009) Boom-and-bust development patterns across the Amazonian deforestation frontier. Science 324:1435-1437

Rodrik D (2007) One economics, many recipes: globalization, institutions and economic growth. Princeton University Press, Princeton, NJ 
Rodrik D (2010) Making room for China in the world economy. Am Econ Rev Papers Proc 100:89-93

Rudel T (2007) Changing agents of deforestation: from state-initiated to enterprise driven process, 1970-2000. Land Use Policy 24:35-41

Sills E, Caviglia-Harris JL (2008) Evolution of the Amazonian frontier: land values in Rondônia, Brazil. Land Use Policy 26:55-67

Solís D, Bravo-Ureta BE, Quiroga RE (2009) Technical efficiency among peasant farmers participating in natural resource management programmes in Central America. J Agric Econ 60:202-219

van der Ploeg R (2011) Natural resources: curse or blessing? J Econ Lit 49:366-420

VanWey LK, Guedes GR, D'Antona AO (2012) Out-migration and land-use change in agricultural frontiers: insights from Altamira settlement project. Popul Environ 34:44-68

World Bank (2003) World development report 2003. World Bank, Washington, DC

World Bank (2008) Word development report 2008: agricultural development. The World Bank, Washington, DC

World Bank (2013) Word development indicators. The World Bank, Washington, DC. http://databank. worldbank.org/data/views/variableselection/selectvariables.aspx? source=world-development-indicators 